\title{
Sclero-Resistance, Sclero-Sensibility and Sclero-Sensitization: The Role of the Tunica Adventitia in Sclerotherapy
}

\section{Ferrara $\mathbf{F}^{1^{*}}$ and Ferrara $\mathbf{G}^{2}$}

${ }^{1}$ Studio Flebologico Ferrara, Italy

${ }^{2}$ Pharmacy Ferrara, Durazzano-Bn, Italy

*Corresponding author: Ferrara F, Studio Flebologico Ferrara 23, via Kuliscioff, 80011 Acerra -Na Italy, Tel: 0039-Off: 081/520723, 3356212337; Fax: 081/0603357; Email: frferr@tiscali.it

Rec date: February 17, 2014, Acc date: April 20, 2014, Pub date: April 28, 2014

Copyright: ( 2014 Ferrara F, et al. This is an open-access article distributed under the terms of the Creative Commons Attribution License, which permits unrestricted use, distribution, and reproduction in any medium, provided the original author and source are credited.

\begin{abstract}
Aim

The aim of this study was to assess the importance of the tunica adventitia in sclerotherapy, measuring scleroresistance, sclero-sensitivity and sclero-sensitization parameters.

\section{Materials and Methods}

900 cases of Great Saphenous Vein (GSV) varicosity treated with Sigg-method sclerotherapy were examined for sclero-resistance as indicated by an ultrasound sclero-resistance marker (SRM+). Sclero-sensitivity was assessed by contact thermography in 356 cases of GSV varicosity with collagen alterations treated with Sigg sclerotherapy. Sclero-sensitization and treatment efficacy were assessed in 50 cases of non-reflux related telangiectasias recurring after a first course of foam microsclerotherapy and retreated with a second sclerotherapy regimen administered together with intradermal glycosaminoglycans (GAG).

\section{Results}

Indicative of incomplete parietal fibrosis, the ultrasound marker SRM+ was most frequently found among patients with recurrence. The degree of sclero-sensibility was found to be inversely proportional to proteoglycan concentrations in the Ground Substance (GS), which in turn was seen to present in differing amounts in the various connective tissue diseases. Sclerotherapy combined with the administration of GAGs proved significantly effective in the treatment of recurrent telangiectasias, indicating GAG sclero-sensitizing properties

\section{Conclusions}

The efficacy of sclerotherapy depends on eliciting a regular fibrotic reaction starting from the connective tissue of the adventitia, which is modulated by ground substance GAG metabolism.
\end{abstract}

\section{Keywords: Sclerotherapy; Proteoglycans; Thermography; Sclero-sensitivity}

Ultrasound

\section{Aim of the Study}

The aim of the study was to assess the role of the tunica adventitia in sclerotherapy.

\section{Introduction}

The Authors use the following definitions [1].

\section{Sclero-resistance}

The condition whereby the venous wall is refractory to all sclerosants
The individual reaction to a particular sclerosant of identical concentration and physical form injected using the same method into same-size veins

\section{Sclero-sensitization}

The variable response of a vein to further sclerotherapy employing the same method of injection and an identical sclerosant of the same physical form and concentration.

\section{Materials and Methods}

This observational, retrospective study was conducted on two groups of patients:

2520 limbs (cases) with primary saphenous varicose veins (C26, Ep, As24, $\pm \mathrm{p}, \operatorname{Pr})$, treated with sclerotherapy according to Sigg's 
Page 2 of 4

technique: injection of iodate solution and immediate compression eccentrically positive $(4 \mathrm{~cm}$ thick rolls, fixed for 7 days with adhesive bandage) and concentric compression (short-elastic bandage extendable at about $35 \%$, reapplied daily for 21 days); an elastic stocking (2nd or 3rd Class) is then worn for 30 days. 50 limbs with telangiectasias not associated with long or short reflux (C1, Ep, As1 \pm 5 , Pr) resistant to an initial sclerotherapy course with $0.25-0.5 \%$ Polidocanol foam and compression with an elastic stocking (2nd or 3rd Class) is then worn for 30 days.

\section{Methods}

Sclero-resistance was assessed by EcoDoppler. At ultrasound the walls of the largest veins (termination of the large and short saphenous) and arteries display a thin line or track at the level of the tunica media. This line is wider than normal $(>0.4 \mathrm{~mm})$ in varicose veins. In a previous study (2005), the Authors suggested that the persistence after sclerotherapy of this anechoic intra-parietal space could be used as a sclero-resistance marker $(\mathrm{SRM}+)$ for the persistence of the "medio-intimal line". This is borne out by the fact that the anechoic line is constantly associated with cases resistant to subsequent sclerotherapy, and is absent in the event of successful treatment (SRM-) [2,3].

Contact thermography $[3,4]$ (a set of plates sensitive to temperatures ranging between $27.5^{\circ} \mathrm{C}$ and $35^{\circ} \mathrm{C}$ ) was used to assess sclero-sensitivity. Thermography provides important information on the function and anatomy of the superficial venous circulation thanks to the local rise in temperature generated not only by the presence of blood in the vessels but also by metabolic activity in the tissues. Thermography is therefore an important diagnostic tool for phlebitis [5]. The temperature rises recorded by thermography are indicative of the vein's reaction to a damage-inducing agent that triggers platelet aggregation, inducing the release of vasoactive amines, which in turn cause hyperemia. Vasoactive amine production is directly proportional to the inflammatory reaction. By reducing vein lumen and content, effective sclerotherapy should reduce the HOT-SPOT (HS) surface area of initial hyperemia, indicative of varices and/or the thermal gradient with nearby tissue by at least $1 \cdot 5^{\circ} \mathrm{C}[3,4]$. Heightened sclero-sensitivity will cause an increase of both $\mathrm{H}$-S surface area and temperature. Conversely, unchanged $\mathrm{H}-\mathrm{S}$ values are indicative of lower sclero-sensitivity. Photographs of limbs pre- and posttelangiectasia treatment were computer processed to assess the degree of sclero-sensitization via the 1-10 Effectiveness Score (ES) that had proved useful in a previous study by the Authors (2012), providing objective numerical indication of treatment efficacy [6].

\section{Materials}

900 of the 2520 cases (C26, Ep, As24, \pm p, Pr) were examined for the prevalence of the SRM+ sclero-resistance marker among successful treatment outcomes and patients with recurrence. The statistical analysis was carried out using the chi-square method.

556 of the 2520 cases (C26, Ep, As24, \pm p, Pr) were assessed with thermography, 356 of whom presented severe connective tissue alterations: old age $>70$ years in 51 cases (Group A); diabetes in 75 cases (Group B); collagen disease in 30 cases (Group C); hypothyroidism in 200 cases (Group D) Table 1. The remaining 200 disease-free cases made up the Control Group. Three levels of sclerosensitivity were defined: low - characterized by unchanged $\mathrm{H}-\mathrm{S} \mathrm{dt}$; high - increased dt; and normal - lower dt. Table 2 shows the sensitivity attributed to all study groups. Statistical results were obtained with a contingency table categorical bivariate analysis (Table 3).

\begin{tabular}{|l|l|l|l|l|}
\hline & & SUCCESS & FAILURES & Total \\
\hline \multirow{2}{*}{ MSR+ } & Count. & 102 & 70 & 172 \\
\cline { 2 - 5 } & $\%$ of Total & $11.33 \%$ & $7.77 \%$ & $19.11 \%$ \\
\hline \multirow{2}{*}{ MSR- } & Count. & 690 & 38 & 728 \\
\cline { 2 - 5 } & $\%$ of Total & $76.66 \%$ & $4.22 \%$ & $80.88 \%$ \\
\hline Total & Count. & 792 & 108 & 900 \\
\hline & $\%$ of Total & $88 \%$ & $12 \%$ & $100.0 \%$ \\
\hline
\end{tabular}

Table 1: Sclero-resistance Marker (SRM+) Distribution in Successful and Recurring Sclerotherapy Cases.

\begin{tabular}{|c|c|c|c|c|c|c|c|}
\hline & & \multicolumn{5}{|c|}{ GROUPS } & \multirow[t]{2}{*}{ Total } \\
\hline \multicolumn{2}{|c|}{ SCLEROSENSITIVITY } & A & B & C & D & control & \\
\hline \multirow{6}{*}{$\begin{array}{l}\text { NORMAL } \\
\text { HIGH } \\
\text { LOW }\end{array}$} & Count & 12 & 15 & 8 & 74 & 148 & 257 \\
\hline & $\%$ of Total & $2.2 \%$ & $2.7 \%$ & $1.4 \%$ & $13.3 \%$ & $26.6 \%$ & $46.2 \%$ \\
\hline & Count & 33 & 56 & 16 & 10 & 45 & 160 \\
\hline & $\%$ of Total & $5.9 \%$ & $10.1 \%$ & $2.9 \%$ & $1.8 \%$ & $8.1 \%$ & $28.8 \%$ \\
\hline & Count & 6 & 4 & 6 & 116 & 7 & 139 \\
\hline & $\%$ of Total & $1.1 \%$ & $0.7 \%$ & $1.1 \%$ & $20.9 \%$ & $1.3 \%$ & $25.0 \%$ \\
\hline \multirow[t]{2}{*}{ Total } & Count & 51 & 75 & 30 & 200 & 200 & 556 \\
\hline & $\%$ of Total & $9.2 \%$ & $13.5 \%$ & $5.4 \%$ & $36.0 \%$ & $36.0 \%$ & $100.0 \%$ \\
\hline
\end{tabular}

Table 2: Distribution into 4 groups of the 556 sclerosed limbs with different sclero-sensitivity assessed with thermography

\begin{tabular}{|l|l|l|l|l|}
\hline $\begin{array}{l}\text { SCLEROSENSITIVITY INFERENTIAL } \\
\text { STATISTICS }\end{array}$ & Value & df & $\begin{array}{l}\text { Asymp. Sig. (2- } \\
\text { sided) }\end{array}$ \\
\hline Pearson Chi-Square & 322.042 & 8 & .000 \\
\hline Likelihood Ratio & 322.713 & 8 & .000 \\
\hline \multirow{2}{*}{\begin{tabular}{l} 
Linear-by-Linear Association \\
\multirow{2}{*}{$\begin{array}{l}\text { Symm.Meas. } \\
\text { (approx. Sig.) }\end{array}$}
\end{tabular}} & Phi & 25.301 & 1 & .000 \\
\cline { 2 - 5 } & Cramer's V & .761 & .000 \\
\cline { 2 - 4 } & $\begin{array}{l}\text { Contingency } \\
\text { Coefficient }\end{array}$ & .606 & & \\
\hline N of Valid Cases & & 556 & \multicolumn{2}{|l}{} \\
\hline
\end{tabular}

Table 3: Inferential statistics of thermography results: statistically significant difference for all Sclero-sensitivity levels among Groups A, $\mathrm{B}, \mathrm{C}, \mathrm{D}$ and controls.

c. 50 cases of micro-sclerotherapy resistant telangiectasias (C1, Ep, As $1 \pm 5, \mathrm{Pr}$ ) were retreated with the multi-therapy treatment protocol (MTT): $0.25-0.5 \%$ Polidocanol foam micro-sclerotherapy combined 
Page 3 of 4

with intradermal injections of a mix of sulfate glycosaminoglycans, composed by Condroitin sulphate $8.5 \%$, Dermatan sulphate $35.5 \%$, Heparan sulphate $47.5 \%$ and Heparin slow $8.5 \%$, in water solution ("GAGs-mix") [6]. Effectiveness scores (ES) were calculated for each of the two treatment courses (Table 4). The degree of sclerosensitization induced by the MTT protocol was calculated using Student's t-test for independent data (Table 5). Photographs were taken using a digital camera with a $50 \mathrm{~mm}$ lens mounted on a tripod at always the same height and distance from the patient, who was always standing for the photographs. Photographs were in black and white and taken under indirect lighting from a $650 \mathrm{~W} / 3000^{\circ} \mathrm{K}$ halogen lamp whose beam was directed at a $45^{\circ}$ angle against a light-colored gray wall. The aim was to ensure that all photographs, whether before or after treatment, were always taken under exactly the same conditions. 4 photographs were taken for each limb: front, back and the two sides, and processed. Median overall luminosity for each limb silhouette was obtained by means of the Histogram function of Photoshop software. Increased luminosity values following treatment were quantified on the above-mentioned visual analogue scale from 0 (no response) to 10 (absence of telangiectasia) and considering each point on the score as corresponding to 2 points on the median luminosity reading. The average score for the 4 photographs per limb was taken as the overall effectiveness score (ES) for each limb (Table 5). Statistical analysis was carried using Student's t test for independent data (Table 5).

\begin{tabular}{|c|c|c|}
\hline \multicolumn{2}{|l|}{$\begin{array}{l}\text { Statistics of ES values } \\
\text { (sclerotherapy) }\end{array}$} & Cases 50 \\
\hline \multicolumn{2}{|l|}{ ES value min } & 1 \\
\hline \multicolumn{2}{|l|}{ ES value max } & 6 \\
\hline \multicolumn{2}{|l|}{ Mean } & 3.6900 \\
\hline \multicolumn{2}{|l|}{ Median } & 4.0000 \\
\hline \multicolumn{2}{|l|}{ Mode } & 6.00 \\
\hline \multicolumn{2}{|l|}{ Std. Deviation } & 1.71990 \\
\hline \multicolumn{2}{|l|}{ Skewness } & -.080 \\
\hline \multicolumn{2}{|l|}{ Std. Error of Skewness } & .337 \\
\hline \multicolumn{2}{|l|}{ Kurtosis } & -1.393 \\
\hline \multicolumn{2}{|l|}{ Std. Error of Kurtosis } & .662 \\
\hline \multirow[t]{3}{*}{ Percentiles } & 25 & 2.0000 \\
\hline & 50 & 4.0000 \\
\hline & 75 & 5.0000 \\
\hline
\end{tabular}

Table 4: Descriptive statistics of Effectiveness Score (ES) distribution after first sclerotherapy course for telangiectasias

\begin{tabular}{|c|c|c|c|c|c|c|}
\hline \multirow{3}{*}{$\begin{array}{l}\text { One- } \\
\text { Sample } \\
\text { Test }\end{array}$} & \multicolumn{6}{|c|}{ Test Value $=3.69$} \\
\hline & \multirow[t]{2}{*}{$\mathrm{t}$} & \multirow[t]{2}{*}{ df } & \multirow[t]{2}{*}{$\begin{array}{l}\text { Sig. (2- } \\
\text { tailed) }\end{array}$} & \multirow[t]{2}{*}{$\begin{array}{l}\text { Mean } \\
\text { Difference }\end{array}$} & \multicolumn{2}{|c|}{\begin{tabular}{llr}
$95 \%$ & \multicolumn{2}{c}{ Confidence } \\
Interval of & the \\
Difference & &
\end{tabular}} \\
\hline & & & & & Lower & Upper \\
\hline
\end{tabular}

\begin{tabular}{|lr|l|l|l|l|l|l|}
\hline $\begin{array}{l}\text { ES } \\
\text { MTT }\end{array}$ & of & 11.311 & 49 & .000 & 2.86000 & 2.3519 & 3.3681 \\
\hline
\end{tabular}

Table 5: One -simple Test. Statistically significant difference between median ES values after the first sclerotherapy course and after MTT treatment of telangiectasias

\section{Results}

The sclero-resistance ultrasound marker $(\mathrm{SRM}+)$ was higher in cases of recurrence compared to successfully treated patients, with a statistically significant difference of $\chi^{2} 162.49$ (corr. Yates); $p<0,001$; odds ratio : 12.46 .

Sclero-sensitivity was seen to be higher in Groups: A (Elderly), B (Diabetes) and C (Collagen Disease) compared to the control group, the difference being statistically significant $(\mathrm{p}<0.001)$, but lower in Group D (Hypothyroidism) (Table 3).

MTT (sclerotherapy combined with intradermal injections of GAGs-mix) was seen to be significantly $(\mathrm{p}<0.001)$, more effective than sclerotherapy alone in treating recurrent telangiectasias (Table 5). MTT was therefore seen to have a sclero-sensitizing effect.

\section{Comment}

The statistically significant association between recurrent telangiectasias and persistence of the anechoic "medio-intimal line" at ultrasound confirms the reliability of this marker (SRM+). On successful sclerosis, the vein no longer displays this anechoic sign between the intima and the adventitia but rather appears as a single ecodense structure. The vein wall reaction to sclerosis is excellent when the tunica media is also involved in the fibrotic reaction. If, on the other hand, it remains unaffected, preserving its elastic muscular elements, recurrence is likely. Histological studies have shown that the only tunica still recognizable after successful vein sclerosis is the adventitia, which is hyperemic and vascularized with connective tissue offshoots reaching into the treatment-induced thrombus [7].

Sclero-sensitivity is significantly influenced by connective tissue pathophysiology. Venous connective tissue comprises three components: cells, fibers and amorphous ground substance (GS). GS seems to play a preponderant role in sclero-sensitivity on account of its three functions: trophic (allowing nutrient exchange between blood and cells); defensive (its viscosity hinders the spread of bacteria); and mechanical (GS cements collagen and elastic fibers) [8]. GS is a multiple-phase colloidal system formed by a dispersing aqueous phase in which various electrolytes are dissolved, and a dispersed phase comprising enzymes, non-structured glycoproteins and proteoglycans. Proteoglycans are made of a protein axis enveloped by negatively charged glycosaminoglycan (GAG) ramifications that attract the positive pole of the dipolar water molecule (Van der Waals forces). Their ability to fix water confers compactness and elasticity to connective tissue [9]. Increased sclero-sensitivity is associated with diseases entailing lower proteoglycans counts, such as diabetes [10] and old age [11]), but also collagen diseases. It has been suggested that collagen conditions are triggered by underlying abnormal cell homeostasis caused by non-enzymatic glycosylation of proteoglycans [12], a metabolic failing causing lowered proteoglycans counts frequently found in aging and diabetes [13]. Conversely, hypothyroidism, which is associated with lower sclero-sensitivity, has 
been shown to present increased concentrations of proteoglycans in the ground substance [14-17].

The greater efficacy of MTT treatment in treating telangiectasias is related to the sclero-sensitizing effect of GAGs-mix. In a previous study (2013), the Authors demonstrated that the connective tissue stimulation achieved with just intradermal injection of GAGs-mix led to more effective sclerotherapy results when treating telangiectasias of a diameter of $<0.3 \mathrm{~mm}[6]$. Since these small veins have no tunica adventitia they are structurally similar to capillaries, the connective tissue of the dermis providing the support normally ensured by the tunica adventitia. By strengthening the GS, GAGs-mix restores the wall support function in telangiectatic vessels. GS chemical-physical properties depend on the degree of long chain GAG polymerization. Moreover, fibroblasts are surrounded by a viscous gel environment comprising highly polymerized GAG that affect both cell kinetics and metabolism [18]. Following sclerotherapy, fibroblast reactivity, in both the inflammatory and proliferative phases, is therefore also impacted also by the chemical-physical balance existing in the pericellular ground substance. GAG administration modulates fibroblast inflammatory and proliferative response, increasing sclerosensitization on account not only of the direct action on the interstitial component of the adventitia but also for its impact on the cell.

\section{Conclusions}

The pathophysiology of venous and arterial intima has been well documented. However, unlike arteries, veins have a thinner media layer and a more developed tunica adventitia whose important nutritional and support functions are sustained not only by the vasa vasorum and its lymphatic system but also by its particular connective tissue that contains a prevalence of Type III collagen and ground substance [19].

Three key conclusions may be drawn from this study.

Sclero-resistance results show that unsuccessful sclerotherapy is associated with a failure of the intima to weld to the tunica adventitia, which, when sclerosis is successful, form a single vein wall thickness.

Sclero-sensitivity is considerably affected by the pathophysiology of the connective tissue of the tunica adventitia.

Sclero-sensitization is affected by GAG administration. It follows that GS is the most important connective tissue component, accounting for the role played by the adventitia in the effectiveness of sclerotherapy. This claim is confirmed by the association of lowconcentration proteoglycans with increased sclero-sensitivity (in diabetes, aging and collagen disease) and conversely by the lower sclero-sensitivity reported in the presence of higher proteoglycan counts (in hypothyroidism).
The tunica adventitia therefore has a major role in sclerotherapy whose effectiveness may be improved by modulating the amorphous ground substance with the administration of sulfate GAG.

\section{References}

1. Ferrara F, Ferrara G (2012) Scleroresistenza, Sclerosensibilità e Sclerosensibilizzazione. Flebologia 1: 14-17.

2. Ferrara F, Bernbach HR (2005) La sclérothérapie des varices récidives. Phlébologie $58 n^{\circ} 2:$ 147-15.

3. Ferrara F (2009) Terapia sclerosante ed elastocompressiva delle flebopatie. Piccin Padova.

4. Ferrara F, Bernbach HR (2001) Résultats de la sclérothérapie compressive: contrôles par écho-Doppler et thermographie. Phlébologie $54 \mathrm{n}^{\circ} 3$ : 301-7.

5. Sandler DA, Martin JF (1985) Liquid crystal thermography as a screening test for deep-vein thrombosis. Lancet 1: 665-667.

6. Ferrara F, Ferrara G (2013) Treating telangiectasias: my method. Minerva Cardioangiol 61: 221-227.

7. Mariani F, Mancini S, Scleroterapia Ed (2006)Minerva Medica, Turin.

8. Funzioni GS Oschman L (1987) The connective tissue and myofascial systems. Copyright, The Rolf Institute, PO Box 1868, Boulder, Colorado, 80306.

9. Hardingham TE, Fosang AJ (1992) Proteoglycans: many forms and many functions. FASEB J 6: 861-870.

10. Anatomia Patologica del Diabete Mellito (consultato il 1 marzo 2013)

11. Curri SB (1986) Le microangiopatie; Artegrafica, Verona.

12. Axford J (1997) Glycobiology and medicine: an introduction. J R Soc Med 90: 260-264.

13. Reiser KM (1998) Nonenzymatic glycation of collagen in aging and diabetes. Proc Soc Exp Biol Med 21:23-27.

14. Rubin R., Strayer D (2011) Rubin's Pathology: Clinicopathologic Foundations of Medicine. Lippincott Williams and Wilkins VI ed.

15. Warner TF, Wrone DA, Williams EC, Cripps DJ, Mundhenke C, et al. (2002) Heparan sulphate proteoglycan in scleromyxedema promotes FGF-2 activity. Pathol Res Pract 198: 701-707.

16. Drobnik J, Ciosek J, Slotwinska D, Stempniak B, Zukowska D, et al. (2009) Experimental hypothyroidism increases content of collagen and glycosaminoglycans in the heart. J Physiol Pharmacol 60: 57-62.

17. Walter K, Krause H (2009) Cutaneous Manifestations of Endocrine Diseases. Springer-Verlag Berlin.

18. Palmieri B (1985)Arteriosclerosi: morfologia di parete e glicosaminoglicani. Nuovo Consorzio Sanitario Nazionale di Roma.

19. Tonar Z, Kural T Jr, Kochová P, Nedorost L, Witter K (2012) Vasa vasorum quantification in human varicose great and small saphenous veins. Ann Anat 194: 473-481. 